\title{
THE PRIEST IN THE MULTILINGUAL CHURCH. LANGUAGE AS AN ASPECT OF THE FUNCTIONING OF THE LOWER CLERGY IN LATE MEDIEVAL PRUSSIA
}

\author{
Marcin Sumowski \\ https://orcid.org/0000-0001-8012-1627
}

\begin{abstract}
Late Medieval Prussia, an area ruled by the Teutonic Order, was a multilingual entity, with the Baltic and Slavic languages used by the local population alongside the German language. This linguistic diversity was a challenge to priests, and to their pastoral work. A command of the languages of their parishioners was crucial for them, as they not only had to teach and hear confession, but also to announce the instructions of the local bishop. So far, historians have discussed the linguistic skills of the clergy mainly in the context of the Christianisation of the native Prussian population. This article deals with the issue by focusing on Late Medieval Prussia and the lower clergy. It discusses the provisions of synodal statutes and papal documents regulating the clergy's command of the languages of their parishioners. The author explores problems of linguistic skill relating to the origin and education of the local clergy, in addition to the impact of the right of patronage and the practical activities of Prussian and Polish chaplains. He also pays attention to the tradition of employing interpreters to support priests who did not know the local Baltic and Slavic languages; this was especially problematic during confession.

KEY WORDS: Teutonic Order; Prussia; Royal Prussia; Medieval clergy; multilingual Church; linguistic skills; pastoral care.
\end{abstract}

\begin{abstract}
ANOTACIJA
Vokiečių ordino valdyta Prūsija vèlyvaisiais viduramžiais buvo daugiakalbis darinys, kuriame, greta vokiečių kalbos, vartotos baltų ir slavų kalbos. Ši kalbinè jivairovè buvo iššūkis kunigams ir ju pastoracinei veiklai. Parapijiečių kalbą jie privalèjo mokèti ne tik siekdami juos mokyti ar išgirsti ju išpažintis, bet ir noredami paskelbti jiems vietos vyskupo valią. Iki šiol istorikai nagrinejjo kunigu kalbinius gebejjimus daugiausia Prūsijos senuju gyventoju christianizacijos klausimo kontekste. Šiame straipsnyje prie klausimo grįžtama susitelkiant i vèlyvuju vidurinių amžių Prūsiją ir žemesniojo lygmens dvasininkiją. Straipsnis aptaria bažnytinių sinodụ statutų nuostatus ir popiežiaus dokumentus, kurie reikalavo, kad dvasininkai mokètụ parapijiečių kalbą. Autorius nagrinèja kalbinių igūdžių problemas, susijusias su vietos dvasininkų kilme ir išsilavinimu, kartu analizuojamas patronato teisės poveikis ir Prūsijos bei Lenkijos kapelionu praktinis aktyvumas. Straipsnyje kreipiamas demesys ir i verteju samdymo tradiciją; šie turèjo talkinti kunigams, kurie nemokèjo vietinių baltų ir slavų kalbų, o tai ypač sukeldavo problemu išpažinties metu.

PAGRINDINIAI ŽODŽIAI: Vokiečių ordinas; Prūsija; Karališkieji Prūsai; viduramžių dvasininkija; daugiakalbẻ Bažnyčia; kalbiniai igūdžiai; sielovada.
\end{abstract}

Marcin Sumowski, dr., assistant at Nicolaus Copernicus University in Toruń, Institute of History and Archival Sciences, Laboratory for a Historical and Geographical Dictionary of Mediaeval Prussia, ul. Bojarskiego 1, PL-87-100 Toruń, Poland. E-mail: m.sumowski@gmail.com 


\section{Introduction}

The parish priest at Heilsberg (today Lidzbark Warmiński) did not know the Prussian language, which turned out to be a significant pastoral problem. The parish he had been serving since 1444 was inhabited by the faithful who spoke German and Prussian (parochianos Theotonicum et Pruthenicum ydeoma communiter vel pro magna parte loquentes). In 1445, the priest received a dispensation for his lack of knowledge of the language (defectus ydiomatis), which, according to the law, should prevent him from having a parish. In a supplication to the Pope in 1447, the priest informed of the number of parishioners, estimating it at 2,000 communicantes, of whom 300 spoke only Prussian. ${ }^{1}$ It turned out that a group of the faithful in the parish did not receive proper pastoral care. The clergyman, appearing in sources under the name of Wichard, was also a canon of the Ermland (today Warmia) cathedral chapter; therefore, he was not always present in the parish. ${ }^{2}$ His parish office was additionally connected with the function of archpriest. ${ }^{3}$ The priest was then allowed to employ a Prussian-speaking chaplain, who could replace him in celebrating the curam animarum.

Linguistic diversity is a very interesting problem in medieval society. ${ }^{4}$ In the context of the clergy, it was recently studied by Enno Bünz, whose study inspired me to these reflections. ${ }^{5}$ Latin was the key language for the medieval clergyman as the language of religious rituals. However, it should be remembered that the social functions of the parish priest were connected with direct contact with the faithful. The priest

1 Repertorium Germanicum. Bd. V: Eugen IV. (1431-1447). Bearb. von Hermann DIENER, Brigide SCHWARZ, Red. Christoph SCHÖNER. Tübingen, 2004, Nr. 9202. See also online version at <http://rg-online.dhi-roma. it/RG/5/9202>, accessed 8 November 2020. I would like to thank Radosław Krajniak for this reference.

2 BORAWSKA, Teresa. Wichard (Heilsberg). In Słownik biograficzny kapituły warmińskiej. Red. Jan GUZOWSKI. Olsztyn, 1996, s. 274. For a more detailed study on Ermland canons, see Radosław Krajniak's dissertation. See also KRAJNIAK, Radosław. Die Prälaten und Kanoniker des ermländischen Domkapitels bis 1466. Zeitschrift für die Geschichte und Altertumskunde Ermlands, 2020, Bd. 64, S. 100-111.

3 RADZIMIŃSKI, Andrzej. Die Kirche im Deutschordensstaat in Preußen (1243-1525). Organisation - Ausstattung - Rechtsprechung - Geistlichkeit - Gläubige (Prussia sacra, 4). Toruń, 2014, s. 58.

4 See Multilingualism in the Middle Ages and Early Modern Age. Communication and Miscommunication in the Premodern World (Fundamentals of Medieval and Early Modern Culture, vol. 17). Ed. by Albrecht CLASSEN. Berlin, Boston, 2016. About 'social history of language': ADAMSKA, Anna. Czy potrzebna nam jest społeczna historia języka? In Historia społeczna późnego średniowiecza. Nowe badania. Red. Sławomir GAWLAS, Michał T. SZCZEPAŃSKI. Warszawa, 2011, s. 189-202. More about languages in Prussia: PÄSLER, Ralf G. Zur Sprachensituation im Deutschordensland Preussen. Ein Problemaufriss. In Ostmitteldeutsche Schreibsprachen im Spätmittelalter (Studia Linguistica Germanica, vol. 89). Hrsg. von Luise CZAJKOWSKI, Corinna HOFFMANN, Hans Ulrich SCHMID. Berlin, New York, 2007, S. 93-107. Recently SZWEDA, Adam. Mehrsprachigkeit in Preußen im Spätmittelalter. In Viele Welten des Ostseeraumes. Annäherungen und Abgrenzungen vom 12. bis ins 15. Jahrhundert. Hrsg. von Beata MOŻEJKO, Paul SRODECKI (forthcoming). The author mentions some issues that are discussed in more detail below. I would like to thank Professor Adam Szweda for sharing this article with me.

5 BÜNZ, Enno. Das Sprachenproblem in der mittelalterlichen Pfarrseelsorge. Beobachtungen in den Lausitzen und anderen Landschaften der Germania Sacra. In Sprachwandel im Deutschen (Lingua Historica Germanica, Bd. 19). Hrsg. von Luise CZAJKOWSKI, Sabrina ULBRICH-BÖSCH, Christina WALDVOGEL. Berlin, Boston, 2018, S. 469-479. 
not only had to teach and hear confession, but also to carry out the will of the local bishop. ${ }^{6}$ Thus, he was the first, and, for many lay people, the only, link with the institutional Church. This essential role in the local community could not be performed without the use of a common language as the basic tool of communication.

This problem is raised in historiography mainly in the context of the Christianisation of the Prussian population. ${ }^{7}$ However, it concerned not only the Prussian language, but also the Slavic languages, especially Polish, which was certainly used in the west and southwest part of the rule of the Teutonic Order. ${ }^{8}$ It is worth considering this issue in relation to the functioning of priests in a linguistically diverse society. These short remarks refer to the parish clergy, i.e. parish priests, chaplains and vicars. I do not analyse this problem with reference to monks. I also do not take up the issue of teaching the faithful, especially the Prussians, as it has already been analysed many times. ${ }^{9}$ Therefore, I did not consider the issue of the 'real' existence of paganism in Prussia in the 15th century, as formulated by Michael Brauer. ${ }^{10}$ Instead, I will try to answer the questions to what extent the knowledge of the language of parishioners determined the image of a good priest, and what the consequences were for the clergy and their careers. However, this analysis should be treated as working hypothesis, which should be revised in future research.

$\star \star \star$

The synodal statutes of the Riga ecclesiastical province of 1428 mentioned the regimen animarum by poorly educated parish priests. What was worse, parish priests

6 See SUMOWSKI, Marcin. Pastor et oves. Parish Priest in Late-Medieval Prussian Town. Quaestiones Medii Aevi Novae, 2018, vol. 23, pp. 357-363.

7 KOSMAN, Marceli. Zanik pogaństwa w Prusach. Komunikaty Mazursko-Warmińskie, 1976, r. 20, nr. 1 (131), s. 23, 25; GÓRSKI, Karol. Zanik dawnych Prusów. Zapiski Historyczne, 1982, t. 47, z. 4, s. 84-85; GÓRSKI, Karol. Problemy chrystianizacji w Prusach, Inflantach i na Litwie [1982]. Komunikaty Mazursko-Warmińskie, 1997, nr. 3, s. 505, 509, 514; BISKUP, Marian. Etniczno-demograficzne przemiany Prus Krzyżackich w rozwoju osadnictwa w średniowieczu (o tak zwanym nowym plemieniu Prusaków) [1991]. In BISKUP, Marian. Opera minora: studia z dziejów zakonu krzyżackiego, Prus, Polski i krajów nadbałtyckich. Toruń, 2002, s. 134; RADZIMIŃSKI, Andrzej. Chrystianizacja i ewangelizacja Prusów. Historia i źródła. Toruń, 2011, s. 36, 50, 54, 55; RADZIMIŃSKI, A. Die Kirche im Deutschordensstaat..., S. 251; MOŻDŻEŃ, Julia. Synkretyzm religijny Prusów na podstawie kroniki Szymona Grunaua. Pruthenia. Pismo poświęcone Prusom i ludom bałtyjskim, 2011, t. VI, s. 231, 232-233; BRAUER, Michael. Die Entdeckung des, Heidentums' in Preußen. Die Preußen in den Reformdiskursen des Spätmittelalters und der Reformation (Europa in Mittelalter: Abhandlungen und Beiträge zur historischen Komparatistik, Bd. 17). Berlin, 2011, S. 163-164, 167-169, 171, 177, 183-184, 185-186. Recently SZWEDA, Adam. Lasset Prewssen Prewssen bleyben. Die Heiden im Ordensland Preußen. Studia historica Brunensia, 2019, vol. 66, no. 2, p. 165. I would like to thank Alicja Dobrosielska PhD and Julia Możdżeń PhD for their valuable comments about the Prussians.

8 Cf. BISKUP, M. Etniczno-demograficzne przemiany..., s. 135, 138-139.

9 See fn 7. Older literature in the cited studies.

10 BRAUER, M. Op. cit. Cf. the criticism of his highly debatable thesis: RADZIMIŃSKI, Andrzej. [Review of:] Michael Brauer, Die Entdeckung des "Heidentums" in Preußen... Zapiski Historyczne, 2014, t. 79, z. 3, s. 183-188; SZWEDA, A. Lasset Prewssen..., pp. 166-168. 
did not know the language of their faithful, which was detrimental to their souls. ${ }^{11}$ It deprived the faithful of the possibiliy to use the necessary food of the Word of God (populo cristiano verbi Dei necessaria subtrahuntur alimenta). Such clergymen were labelled as unworthy (indigni pastores). The question of the priest's language skills was included in the general model of the priest. ${ }^{12}$ It was ordered that priests put forward for pastoral positions should exhibit knowledge, the appropriate age, good manners and a command of the language of their parishioners. ${ }^{13}$ Pastoral prebend holders who did not meet the last of these requirements had to provide a chaplain within one year to perform their preaching duties for them. Otherwise, they were in danger of losing their parish.

The local norms of Church law correspond to the supplication cited above of the parish priest from Heilsberg. A reference to the language of pastoral care can also be found in the statutes of the Ermland diocese of 1449 and 1497, to which the town belonged. ${ }^{14}$ If there were both German and Prussian believers in the parish, ${ }^{15}$ the parish priest was obliged to provide the latter with a Prussian chaplain who could teach them. If, however, he could not hire a Prussian clergyman, the obligation to instruct in the faith rested with the German chaplain. In the Pomesanian statutes of 1411 , it was also indicated that a parish priest who failed to speak the language of the parishioners had to provide them with a suitable priest. ${ }^{16} \mathrm{It}$ is noteworthy that it was the parish priest's duty to find a clergyman with the appropriate language skills. This was also mentioned in the statutes of the Włocławek diocese (in the Kingdom of Poland) to which Pomerelia (today Pomorze Gdańskie) belonged. In the codification of 1402, it was decided that a parish priest with parishioners whose language he did not know was obliged to employ a priest who spoke it. As in the case of the Riga statutes, the failure to comply with this requirement could result in the loss of the benefice. ${ }^{17}$ Owing to the high costs, the employment of such a priest was not always

11 Constitutiones synodales Warmienses, Sambienses, Pomesanienses, Culmenses, necnon provinciales Rigenses. Ed. Franz HIPLER. Brunsbergae, 1899, col. 309, No III: 'pastores mutos, ideoma suarum ovium intelligibiliter loqui nescientes, in sue proprie salutis et multarum animarum dispendium'.

12 See SUMOWSKI, Marcin. Wzorzec duchownego w średniowiecznej instrukcji wizytacyjnej Inquisitorium clericorum z diecezji sambijskiej. In Collegarum et Discipulorum Gratitudo. Studia ofiarowane prof. Andrzejowi Radzimińskiemu z okazji 60. urodzin. Red. Radosław BISKUP, Krzysztof KWIATKOWSKI. Toruń, 2018, s. 197-214.

13 Constitutiones synodales..., col. 309, No III: 'idoneos literarum sciencia, etate ac morum probitate et singulariter ideoma parochianorum proferre scientes'.

14 Ibid., col. 18-19, No 29, col. 31, No 35; BRAUER, M. Op. cit., S. 182-183.

15 About mixed parishes in Prussia: BISKUP, Marian. Uwagi o problemie osadnictwa i sieci parafialnej w Prusach Krzyżackich w XIV i XV wieku [1983]. In BISKUP, M. Opera minora..., s. 161-166.

16 Constitutiones synodales..., col. 276, No 24: 'Item quilibet sacerdos habens populum cuius ydeoma ignorat provideat ei de sacerdote, qui in ydeomate et lingwaio eidem populo sit conformis'; BRAUER, M. Op. cit., S. 185.

17 Statuta Synodalia Dioecesis Wladislaviensis et Pomeraniae. Coll. et ed. Zenon CHODYŃSKI. Varsaviae, 1890, p. 4: 'Ut quilibet plebanus qui habet parochianos, quorum linguam ignorat, diliganter provideat eis de eodem idiomate sacerdotem, sub poena privationis beneficii.' 
possible, which was pointed out in the Riga statutes quoted above, instructing the bishops to take care of this problem. In Ermland, in such cases, the use of an interpreter was allowed, as discussed below.

The requirement to employ chaplains for the Prussian population was connected with the need to educate and ordain an appropriate number of Prussians. Johann Merkelin, the Augustinian friar and author of the Ermland handbook for 'simple' priests, mentioned in the prologue that the bishop did not know the language of neophytes (defectus idiomatis), so he had to delegate appropriate priests to pastoral tasks. ${ }^{18}$ Schools educating the Prussians were to serve the purpose of proper preparation. In Frauenburg (today Frombork), each of the chapter's canons was to educate a boy who spoke this language. ${ }^{19}$ In turn, at the bishop's castle in Heilsberg there was a school for 12 Prussians. ${ }^{20}$ These scolares [...] lingwaii prothencialis were supposed to teach their countrymen (pro [...] informacione prothenorum). ${ }^{21}$

The problem of language was crucial here. It is worth quoting an account of a conversation at the court of Pope Innocent VI which was held in the presence of a certain Prussian by the bishop-elect of Ermland, Johann Stryprock, ${ }^{22}$ around 1355. The Pope was astonished at the intellectual level of this Prussian, which prompted the head of the Church to ask about the language of the pastoral ministry. The new bishop replied that he did not know the Prussian language, and that teaching was done by an interpreter. The Pope replied, referring to the gift of tongues given to the apostles, that the newly Christianised people should be taught in their own language (Necesse esset, ut heberent plures in suo lingwaiio). ${ }^{23}$ Other ordinances corresponded with this conviction. The synodal statutes reiterated that the duties of pastors included

18 MERKELIN, Jan. Liber de instructione simplicium sacerdotum. Pars 1 (Textus et Studia. Historiam Theologiae in Polonia Excultae Spectantia, vol. 12, fasc. 1). Pub. Marian BORZYSZKOWSKI. Warszawa, 1982, p. 24, 72; BRAUER, M. Op. cit., S. 181-182.

19 Ordinancia castri Heylsbergk. In Scriptores Rerum Warmiensium. Bd. I. Hrsg. von Carl Peter WOELKY, Johann Martin SAAGE. Braunsberg, 1866, S. 341-342: 'canonici eiusdem ecclesie [...] unusquisque habet educere puerum in curia sua lingwa prothenicali, ut populum sibi subditum de quo vivunt, habeant eos decere et educere katholica fide et ne pereant in animabus eorum'; BORZYSZKOWSKI, Marian. Szkoły diecezji warmińskiej w okresie od XIII do połowy XVI wieku. Studia Warmińskie, 1965, t. II, s. 44; BORAWSKA, Teresa. Życie umysłowe na Warmii w czasach Mikołaja Kopernika. Toruń, 1996, s. 60; BRAUER, M. Op. cit., S. 181. The source cited here is the ordinance organising life at Heilsberg Castle. It came from the second half of the 15th century, but, as we will see, sometimes refers to earlier times. See JARZEBOWSKI, Marc. Die Residenzen der Preussischen Bischöfe bis 1525. Toruń, 2007, S. 202-211.

20 BORZYSZKOWSKI, M. Op. cit., s. 51-56; BORAWSKA, T. Życie umysłowe..., s. 64-65; JARZEBOWSKI, M. Op. cit., S. 208; BRAUER, M. Op. cit., S. 180-181.

21 Ordinancia castri Heylsbergk..., S. 337.

22 Cf. BORAWSKA, Teresa. Stryprock (Streifrock) Jan. In Słownik biograficzny..., s. 238-239; KOPIEC, Jan; GLAUERT, Mario. Johannes Stryprock (Streifrock). In Die Bischöfe des Heiligen Römischen Reiches 11981448. Ein biographisches Lexikon. Hrsg. von Erwin GATZ, Clemens BRODKORB. Berlin, 2001 (hereinafter BHRR 1198-1448), S. 184.

23 Ordinancia castri Heylsbergk..., S. 344; BORZYSZKOWSKI, M. Op. cit., s. 53, przyp. 109; JARZEBOWSKI, M. Op. cit., S. 208. 
teaching in vulgari, both in proclaiming the Gospel and in teaching basic prayers. ${ }^{24}$ In Pomesania, according to the statutes of 1480, this obligation was applied especially to parishioners using the Polish or Prussian language (maxime Polonis et Prutenis). ${ }^{25}$ Upon the statutes of the bishop of Ermland Heinrich Sorbom, ${ }^{26}$ the successor of Johann Stryprock, the parish priest was obliged to teach in German and Prussian. ${ }^{27}$ Even more demanding was the papal bull of 1426, issued at the request of Bishop Franz Kuhschmalz ${ }^{28}$ and the cathedral chapter. ${ }^{29}$ It highlighted the linguistic diversity of many parishes of Ermland, which often did not correspond to the skills of priests. The Prussians who did not know German could not be well instructed in the faith if their priest spoke only German (parrochiani tantum pruthenicum loqui scientes [...] in fide catholica male instruuntur, cum verbum dei in teotunico a rectoribus tantum teotunicum loqui scientibus nequeantum intelligere). Therefore, the Pope ordered that in mixed parishes only clergymen who knew both languages should be parish priests. The memory of this decision continued to survive in the diocese later. ${ }^{30}$ Michael Brauer treated the bishop's initiative as a step against the substitute pastoral service executed by the Prussian chaplain, which only delayed but did not solve the essence of the linguistic problem. ${ }^{31}$ It seems, however, that in this case it was associated rather with the problem of confession and patronage over parishes (see below).

The cited papal decision was referred to in a document for Andreas Lumpe ${ }^{32}$ of $1455 .{ }^{33}$ By way of exchange, the clergyman took over the parish in Heilsberg. Like his predecessors, the above-mentioned Wichard and Caspar Buls, he did not know the Prussian language. ${ }^{34}$ He received a dispensation from this (quodque tu ydeoma

24 Constitutiones synodales..., col. 264, No 17 [Formularz z Uppsali. Późnośredniowieczna księga formularzowa biskupstw pruskich (Fontes - Towarzystwo Naukowe w Toruniu, t. 109). Red. Radosław BISKUP. Toruń, 2016, Aneks/Anhang I, s. 340, new edition], col. 271-272, No 5; col. 276-277, No 27; RADZIMIŃSKI, A. Chrystianizacja..., s. 38, 40, 49-50; BRAUER, M. Op. cit., S. 178-179, 180. Constitutiones synodales..., col. 288, No 5.

26 Cf. BORAWSKA, Teresa. Sorbom (Sauerbaum) Henryk. In Słownik biograficzny..., s. 230-231; KOPIEC, Jan; GLAUERT, Mario. Heinrich Sorbom (Sauerbaum). In BHRR 1198-1448, S. 184-185.

27 Constitutiones synodales..., col. 3, No 11; BORZYSZKOWSKI, M. Op. cit., p. 55.

28 Cf. BORAWSKA, Teresa. Kuhschmalz (de Resel) Franciszek. In Słownik biograficzny..., s. 137-138; KARP, Hans-Jürgen. Kuhschmalz, Franz. In Die Bischöfe des Heiligen Römischen Reiches 1448-1648. Ein biographisches Lexikon. Hrsg. von Erwin GATZ, Clemens BRODKORB. Berlin, 1996, S. 398.

29 Eine Verordnung Papst Martin V. über die preußische Sprache in Ermland. Pastoralblatt für die Diöcese Ermland, 1891, 23. Jhg., Nr. 7, S. 90; Codex Diplomaticus Warmiensis. Bd. IV: Urkunden der Jahre 1424-1435 und Nachträge. Hrsg. von Viktor RÖHRICH, Franz LIEDTKE, Hans SCHMAUCH. Braunsberg, 1935, S. 143, Nr. 83; BORZYSZKOWSKI, M. Op. cit., s. 55, przyp. 119; BÜNZ, E. Op. cit., S. 475-476.

30 Ordinancia castri Heylsbergk..., S. 345-346; JARZEBOWSKI, M. Op. cit., S. 208.

31 BRAUER, M. Op. cit., S. 183.

32 Cf. BORAWSKA, Teresa. Lumpe (alias Cannengiesser) Andrzej. In Słownik biograficzny..., s. 155; KRAJNIAK, Radosław. Andreas Lumpe. In Gedanopedia, URL: <https://www.gedanopedia.pl/gdansk/?title=LUMPE_ ANDREAS>, accessed 27 October 2020. See fn 2.

33 Vetera monumenta Poloniae et Lithuaniae gentiumque finitimarum historiam illustrantia: maximam partem nundum edita ex tabulariis Vaticanis. T. II: 1410-1572. Ab Augustin THEINER. Romae, 1861, p. 97-98, No 141; BRAUER, M. Op. cit., S. 184.

34 BORAWSKA, Teresa. Buls (Bols, Bulsz, Booltz) Kaspar. In Słownik biograficzny..., s. 29. See fn 2. 
Pruthenicum ignores [...] de speciali gratia dispensamus). However, it was emphasised that the majority of parishioners spoke German (parrochiani pro maiori parte ydeoma Theotonicum locuntur). This corresponded to the number of Prussians given in the document quoted at the beginning. This example shows, on one hand, the durability of the norm, but, on the other hand, it proves how poorly the clergy adapted themselves to the situation. It should also be added that the papal document failed to mention the employment of a possible interpreter this time.

Practical pastoral difficulties were solved in various ways. In the castle in Heilsberg, to which we shall return once again, there was a penitentiary office (penitencionarius), who spoke Prussian. ${ }^{35} \mathrm{He}$ was employed upon a papal order. This office remained in operation regularly until the times of Bishop Franz Kuhschmalz, who did not always appoint somebody to the office. ${ }^{36}$ The official's duties included visiting parishes, especially Prussian ones, where he was to preach the Word of God in the local language (propria lingwa). He was also obliged to preach in the Prussian language on Sundays and holidays in the Church of St Catherine in Heilsberg. Incidentally, it is worth adding that the last of these duties could relieve the local parish priest, who, as we have seen, did not use the language of some of their parishioners. However, the penitentiary did not visit all parishes. The archpresbyterate of Frauenburg and Elbing (today Elbląg) were visited by one of the canons with a companion who knew the Prussian language (qui erat ydeomate pro prothenis). ${ }^{37}$

Such substitute measures could not solve the problem of the linguistic ignorance of the parish priests. It is impossible to say how many of them actually came from non-German-speaking circles. Prosopographic research on the lower clergy indicates rather a bourgeois, and therefore predominantly German, origin. ${ }^{38}$ It should of course be borne in mind that these analyses mainly concern specific groups of the urban clergy. However, when we look at the more general list of ordained clergy in the Pomesanian diocese in the years 1480 and 1481, we see a clear advantage of burghers. ${ }^{39}$ Undoubtedly, those who spoke the local language also became clergymen. ${ }^{40}$ In the case of the Prussians, this possibility was already mentioned in the treatise of Christburg (today Dzierzgoń) of 1249.41 However, without detailed

35 Ordinancia castri Heylsbergk..., S. 322, 341; BORZYSZKOWSKI, M. Op. cit., s. 54-55; JARZEBOWSKI, M. Op. cit., S. 207-208, 242; BRAUER, M. Op. cit., S. 181.

36 Cf. BRAUER, M. Op. cit., S. 183.

37 Ordinancia castri Heylsbergk..., S. 338.

38 See SUMOWSKI, Marcin. Duchowni diecezjalni w średniowiecznym Toruniu. Studium prozopograficzne. Toruń, 2012, s. 70-76, 82-85.

39 SUMOWSKI, Marcin. Święcenia duchowieństwa w późnośredniowiecznych Prusach. Roczniki Historyczne, 2019 , r. 85, s. 65-68.

40 Karol Górski assumed that in the 14th century the Teutonic Order began to accept priests of local origin into its ranks: GÓRSKI, K. Problemy chrystianizacji w Prusach..., s. 515-516.

41 Preussisches Urkundenbuch. Politische Abtheilung. Bd. I, 1. Hälfte. Hrsg. von Rudolf PHILIPPI, Carl Peter WOELKY. Königsberg, 1882, S. 158-165, Nr. 218: 'et ut ipsi et filii eorum legitimi possint esse clerici et religionem intrare'; RADZIMIŃSKI, A. Chrystianizacja..., s. 50. 
research, it is difficult to say what percentage of locals decided to pursue a Church career, and how often these clergymen became parish priests or chaplains. It cannot be assumed that as early as the 15th century the school in Heilsberg educated a sufficient number of auxiliary priests. ${ }^{42}$

In the case of Prussia, we know about some individual cases. Albert Pruthenus acted in 1326 as a parish priest in Wormditt (today Orneta). ${ }^{43}$ The most famous is Bando, a parish priest in Christburg and later in Preußisch Holland (today Pasłęk). ${ }^{44}$ However, compared to other municipal priests, they seemed to be rare. Perhaps it was village priests that used the language of parishioners more often. The later chronicler Lucas David (1503-1583) was to know the parish priest from Groß Klebergk (today Klebark Wielki) near Allenstein (today Olsztyn), who was a student from the abovementioned school in Heilsberg. ${ }^{45}$ This does not prejudge his knowledge of the Prussian language, but indirectly points to it. However, it seems that also among rural parishioners, the language skills did not reflect the diversity of parishioners, which suggests the common use of an interpreter (see below). With regard to older historiography, this was commented on by Michael Brauer. The researcher rightly said that the belief that a knowledge of the Prussian language was common among the clergy was incorrect. ${ }^{46}$ It seems exaggerated by Karol Górski to say that the clergy who came to Samland in the 14 th century 'must have [...] been familiar with the Polish and Prussian languages. ${ }^{\prime 47}$ Knowledge about language requirements could be common among the clergy in the 15th century. We can assume that clerics more or less understood their social roles, which was framed in normative sources. Nevertheless, this did not mean that the clergy were fully adapted to this requirement. Of course, it is difficult to judge mainly on the basis of normative sources. Their narrative is to some extent a cultural, repetitive manner, and it does not always reflect reality. ${ }^{48}$ However, general standards have to be understood in the local context, ${ }^{49}$ which in this case is the specific situation of relatively young Christianity in Prussia.

42 Cf. BISKUP, M. Uwagi o problemie osadnictwa..., s. 166; BRAUER, M. Op. cit., S. 183.

43 Codex Diplomaticus Warmiensis. Bd. I: Urkunden der Jahre 1231-1340. Hrsg. von Carl Peter WOELKY, Johann Martin SAAGE. Mainz, 1860, S. 378-379, Nr. 224.

44 BIAŁUŃSKI, Grzegorz. Bando - pleban pasłęcki. Przyczynek do kariery Prusów w państwie zakonu krzyżackiego. In Ad fontes: Studia ofiarowane Księdzu Profesorowi Alojzemu Szorcowi w siedemdziesięciolecie urodzin. Red. Zoja JAROSZEWICZ-PIERESŁAWCEW, Irena MAKARCZYK. Olsztyn, 2006, s. 52-59.

45 Lucas David's [...] Preussische Chronik. Bd. II. Hrsg. von Ernst HENNIG. Königsberg, 1812, S. 122; BORZYSZKOWSKI, M. Op. cit., s. 54; BORAWSKA, T. Życie umysłowe..., s. 65, przyp. 61.

46 BRAUER, M. Op. cit., S. 169.

47 GÓRSKI, K. Problemy chrystianizacji w Prusach..., s. 515.

48 See SUMOWSKI, M. Wzorzec duchownego..., s. 204.

49 About this issue: SUMOWSKI, Marcin. Sie das nit thun, das heissen aber lernnen. Wizerunek niższego duchowieństwa w późnośredniowiecznym Gdańsku. In Danzig in der frühen Neuzeit. Kultur, Religion, Politik, Gesellschaft und internationale Beziehungen = Gdańsk w okresie nowożytnym. Kultura, religia, polityka, społeczeństwo i stosunki międzynarodowe. Red. Wiesław DŁUGOKĘCKI, Jürgen SARNOWSKY. Gdańsk (forthcoming). 
The problem of the language skills of parish priests can be considered in the context of the right of patronage. In the case of most parishes in Prussia, this right belonged to the territorial authority, the Teutonic Order. ${ }^{50}$ Obtaining a parish, especially a town parish, had to be associated with prior ties with the authorities, which rewarded a person with a prebend. It is precisely in this problem that we should see the source of the quoted request of the Bishop of Ermland, which resulted in the papal decree on bilingualism of the parish priests. Perhaps this initiative was to force patrons to present priests with appropriate skills to take over parishes. It is true that in the area of the episcopal dominion and the chapter, it was the ordinary and canons who patronised most of the churches, but in the rest of the diocese's territory, the Teutonic Order had the advantage. ${ }^{51}$ The main criterion for promotion here was not appropriate pastoral skills, but merits for the benefit of both central and local authority, the commandry. This limited the local possibilities. The representatives of richer Prussian families, for generations associated with the Teutonic Knights, ${ }^{52}$ could rather pursue a priest's career. This was exactly the case with the parish priest Bando, who additionally received a good education and was employed in the chancellery of the grand master before taking the prebend. ${ }^{53}$ Perhaps he knew not only Prussian, Latin and German, but also Polish. ${ }^{54}$ It can be assumed, however, that he was an exceptional figure among his colleagues.

The very fact of joining the ranks of the clergy was associated with language skills. Obtaining holy orders required appropriate intellectual preparation. The requirements were not very high, because to meet them it was enough to study at the parish school or to be taught by a parish priest. ${ }^{55}$ However, even if the priest did not know the mother tongue of the parishioners, the candidate for ordination had to master not only Latin but also German. On the other hand, it is difficult to assume that German-speaking clergymen from towns would make the effort to learn a foreign language only to work in a rural parish. ${ }^{56}$ After all, it was not necessary to take over the most profitable prebends. As we have seen, in practice, even the requirement to know the parishioners' native language could be circumvented.

It can be assumed that for the above reasons many parish priests were not fluent in two languages. Therefore, Prussian and Polish-speaking parishioners needed some form of replacement. In practice, in many cases it could have been more a request than reality. Certainly, the situation of town priests was easier. Wealthy parish priests

50 RADZIMIŃSKI, A. Die Kirche im Deutschordensstaat..., S. 242-245.

51 Ibid., S. 244.

52 See DOBROSIELSKA, Alicja. Opór, oportunizm, współpraca. Prusowie wobec zakonu krzyżackiego w dobie podboju. Olsztyn, 2017, s. 149-194.

53 BIAŁUŃSKI, G. Op. cit., s. 53-56.

54 Ibid., S. 59.

55 SUMOWSKI, M. Święcenia duchowieństwa..., s. 33-34.

56 Cf. BISKUP, M. Etniczno-demograficzne przemiany..., s. 134. 
could afford to employ chaplains who had appropriate skills. Andreas Sandberg, the priest in Strasburg (today Brodnica) noted in accounts of 1445 that, according to the custom, two Polish preachers had gone to nearby villages to hear the confessions of the faithful. ${ }^{57}$ Presumably, the inhabitants of these places used the Polish language. In Strasburg itself, there was a Polish chapel. ${ }^{58}$

In the western part of the Teutonic rule, the linguistic problem concerned mainly the Polish population. The response to it was the activity of Polish preachers and chaplains. They were probably from local families, but certainly some of them came from the areas of the adjacent Polish dioceses, Włocławek and Płock. ${ }^{59}$ Let us list a few examples of such priests. There were clergymen performing such functions in Elbing, ${ }^{60}$ e.g. Jacob (Polensschen prediger, Polesschen caplan, her lacob der Polen) in the years 1411-1413.61 In 1474, in one of the wills, there appeared Nicolaus polnischen prediger, who was at the same time the testator's confessor. ${ }^{62}$ On the other hand, a chaplain Stanisław was registered in the book of the porters' brotherhood. ${ }^{63}$ Polish preachers were also mentioned in other large towns, such as Culm (today Chełmno) ${ }^{64}$ and Danzig (today Gdańsk), ${ }^{65}$ but they also performed in small centres. Chapels referred to as 'Polish' can be found in the above-mentioned towns of Strasburg and Marienburg (today Malbork). ${ }^{66}$ For example, it is worth taking a closer look at the chapel of St Barbara in Löbau (today Lubawa). It was built around 1505 at the parish cemetery, and was intended for the Polish population (pro natione scilicet Polonica). The vicar was obliged to celebrate mass there on Sundays and holidays. It was underlined that the reason for this was the large number of Polish believers. ${ }^{67}$

57 Accounts of parish priest in Strasburg, 1439-1445. Geheimes Staatsarchiv Preussischer Kulturbesitz (Prussian Privy State Archives, Berlin-Dahlem, hereinafter GStA PK), Ordensbriefarchiv (hereinafter OBA), Nr. 9026, fol. $12 r$.

58 Ibid., fol. 4r, 5v, 6r; CZAJA, Roman. Dzieje miasta w średniowieczu (XIII wiek- 1466 rok). In Brodnica. Siedem wieków dziejów miasta. Red. Jerzy DYGDAŁA. Brodnica, 1998, s. 95.

59 Cf. The above quoted list of the ordained: SUMOWSKI, M. Święcenia duchowieństwa..., s. 64.

60 See JÓZEFCZYK, Mieczysław. Średniowiecze Elblagga. Z problematyki społeczno-religijnej. Elbląg, 1996, S. 201-202.

61 Nowa księga rachunkowa Starego Miasta Elblaga (1404-1414). Cz. 2: (1411-1414) (Fontes - Towarzystwo Naukowe w Toruniu, t. 73). Red. Markian PELECH. Warszawa, Poznań, Toruń, 1989, s. 7-8, nr 1164; s. 8-9, nr 1166; s. 34-35, nr 1261; s. 57, nr 1330.

62 KUBICKI, Rafał. Testamenty elbląskie. Studium z dziejów miasta i jego mieszkańców w późnym średniowieczu. Gdańsk, 2020, s. 257-258.

63 The book of the Porters' brotherhood in Elbing, 15th c. Archiwum Państwowe w Gdańsku (State Archives in Gdańsk), 426, 1.

64 Register of rents in Culm, 15th c. GStA PK, XIV. HA, 322A, Nr. 4, S. 277.

65 GÜNTHER, Otto. Andreas Slommow und Johannes Zager in den Handschriften der Danziger Marienbibliothek. Zeitschrift des Westpreussischen Geschichtsvereins, 1917, Hf. 57, S. 150-152.

66 Paul de Luebeschyn to the chaplain of the Grand Master, 27 May 1430. GStA PK, OBA, Nr. 5374. Polish preachers and chaplains from Marienburg: The book of the Corpus Christi brotherhood in Marienburg, 15th c. Archiwum Archidiecezji Warmińskiej w Olsztynie (Archdiocese of Warmia Archives, Olsztyn), AB H 196 , fol. $16 r, 36 r$.

67 Urkundenbuch des Bisthums Culm. Bd. I, Th. 2: Das Bisthum Culm unter Polen. 1466-1774. Bearb. von Carl Peter WOELKY. Danzig, 1887, S. 627-628, Nr. 769. 
We can find frequent accounts of such clergymen for Thorn (today Toruń). ${ }^{68}$ It was probably related to the growing Polish population in this city in the 15th century. ${ }^{69}$ In 1409, a Polish preacher called Heinrich ${ }^{70}$ appeared in the New Town of Thorn. In turn, at least in the years 1431-1437 there was another preacher and vicar, Nicolaus. ${ }^{71}$ In 1509, the Polish chaplain Peter was recorded in sources. ${ }^{72}$ In a similar period, at the beginning of the 16 th century, Simon, even known as Polonus, ${ }^{73}$ was active. Jacob Broseck, vicar in 1541, was referred to in a similar way. ${ }^{74}$

Perhaps most Polish chaplains were vicars of private altars. It is therefore reasonable to ask to what extent they could participate in the pastoral ministry. The parson did not hire them directly, and therefore they were not fully subordinate to him. However, these clergymen were often obliged to help the head of the parish at certain periods of time. ${ }^{75}$ Thus, they could support his activities in relation to parishioners whose language he did not speak.

The statutes of Ermland cited above drew attention to an interesting aspect of the linguistic problems. The statutes made it possible for an interpreter to fulfil pastoral obligations (per interpretem) as long as the parish priest could not hire an appropriate priest. ${ }^{76}$ It seems that the sermon was to be translated simultaneously while it was delivered in German. However, the nuisance of this solution was noticed. Therefore, the possibility of alternating preaching was anticipated as long as the Prussians did not understand the German language. The Pope was to point out the difficulties of teaching through an interpreter during the above-mentioned meeting. ${ }^{77}$

68 SUMOWSKI, Marcin. Kler diecezjalny w społeczeństwie średniowiecznego Torunia - przyczynek do badań nad funkcjonowaniem duchowieństwa miejskiego epoki. In Kościół i duchowieństwo w średniowiecznej Polsce i na obszarach sąsiednich. Red. Radosław BISKUP, Andrzej RADZIMIŃSKI. Toruń, 2013, s. 177; SUMOWSKI, Marcin. Duchowieństwo parafialne Nowego Miasta Torunia i jego społeczne oddziaływanie w średniowieczu. In Nowe Miasto Toruń. 750 lat lokacji. Red. Krzysztof MIKULSKI, Piotr OLIŃSKI, Waldemar ROZYNKOWSKI. Toruń, 2014, s. 92-93.

69 See MIKULSKI, Krzysztof. Struktura etniczna mieszkańców i status społeczny ludności pochodzenia polskiego w Toruniu od końca XIV do połowy XVIII wieku. Roczniki Humanistyczne, 1997, t. 63, s. 111-129.

70 Księga ławnicza Nowego Miasta Torunia (1387-1450) (Fontes - Towarzystwo Naukowe w Toruniu, t. 63). Wyd. Karola CIESIELSKA. Warszawa, Poznań, 1973, s. 46, nr 434; SUMOWSKI, M. Duchowni diecezjalni..., s. 133-134.

71 Księga ławnicza Nowego Miasta..., s. 167-168, nr 1449; s. 219, nr 1805; SUMOWSKI, M. Duchowni diecezjalni..., s. 216.

72 Księga ławnicza Starego Miasta Torunia (1479-1515). Cz. 2: (1502-1515) (Fontes - Towarzystwo Naukowe w Toruniu, t. 113). Wyd. Krzysztof KOPIŃSKI, Krzysztof MIKULSKI, Janusz TANDECKI. Toruń, 2018, s. 683, $\mathrm{nr} 2040$.

73 Bishop of Culm to Simon, Polish preacher in Thorn, 11 March 1519. Archiwum Państwowe w Toruniu (State Archives in Toruń), Kat. I, nr 2878/13; SUMOWSKI, M. Duchowni diecezjalni..., s. 244-245.

74 GÓRSKI, Karol; GOŁEMBIOWSKI, Maciej. Wykaz prebend kościelnych Torunia z 1541 roku. Zapiski Historyczne, 1977, t. 42, z. 4, s. 152; SUMOWSKI, M. Duchowni diecezjalni..., s. 138.

75 SUMOWSKI, M. Pastor et oves..., s. 369-371.

76 Constitutiones synodales..., col. 18-19, No 29; col. 31, No 35; BÜNZ, E. Op. cit., S. 476.

77 Ordinancia castri Heylsbergk..., S. 344: 'Durum est informare populum per interpretem.' 
Hearing confession in such circumstances was a complicated issue. It was not only a practical issue, but also a theological one. ${ }^{78}$ One of the questions asked during the visit to the Samland diocese was related to the betrayal of the seal of the confessional. However, a reference was made to interpreters who were also obliged to keep it. ${ }^{79}$ It was an expression of local practice. The statutes of Samland at the beginning of the 14th century allowed confession only through an adult interpreter, except for legitimate reasons, such as the danger of death. ${ }^{80} \mathrm{~A}$ similar permit was also included in the codification of $1427 .{ }^{81}$ However, this should be seen as the sanctioning of pastoral necessity. Confession through an interpreter was very problematic from the perspective of the Church authorities. The cited papal bull of 1426 suggested that this necessity made a sin public, which hindered the sincerity of the confession, and might lead to scandal. ${ }^{82}$ The Council of Basel in 1435 spoke in a similar vein in response to the request of the Sambian bishop. Michael Junge (bishop in the years 1425-1442) ${ }^{83}$ reported that many parish priests in his diocese, especially near Samogitia, did not know the language of their parishioners, which entailed consequences for confession, as it discouraged the faithful from the sacrament. ${ }^{84}$ As a result, it was ordered to appoint in parishes only clergymen who knew the language of their parishioners and could carry out their duties without an interpreter (personaliter absque alicuius interpretacionis adminiculo audire possent). In practice, this meant a regulation analogous to the one in Ermland, reserving mixed parishes for bilingual priests. The documents cited suggest that the participation of third parties in the confession contradicted its private nature. As Michael Brauer rightly pointed

78 See the remark BRAUER, M. Op. cit., S. 171: 'Wenn der Priester die Beichte nicht versteht und eine unangemessene Buße verordnet oder wenn der Gläubige die Bußauflagen nicht versteht - was geschieht dann mit dem Sakrament der Beichte? Können die Sünden auf diese Weise vergeben werden? Ein komplexes theologisches Problem.'

79 SUMOWSKI, M. Wzorzec duchownego..., s. 207, nr. 3.

80 KROLLMANN, Christian. Eine merkwürdige samländische Urkunde. Altpreußische Forschungen, 1934, 11. Jhg., S. 36-37: 'Preterea sacerdotes, qui linguam volencium sibi confiteri non noverint, non nisi per interpretem virum adultum confessionem audiant, nisi contigerit ex mortis articulo aut alia necessitate legitima aliter faciendum'; GÓRSKI, K. Problemy chrystianizacji w Prusach..., s. 514; RADZIMIŃSKI, A. Chrystianizacja..., s. 55; RADZIMIŃSKI, A. Die Kirche im Deutschordensstaat..., S. 251.

81 Constitutiones synodales..., col. 262, No 5; Formularz z Uppsali..., s. 338: 'Preterea sacerdotes ideoma sibi confiteri volencium non intelligentes, pro viros vel mulieres dumtaxat necessitate urgente, discretos interpretes audiant confessiones.'

82 Eine Verordnung Papst Martin V...., S. 90: 'et tunc illi volentes confiteri per interpretem necessariu habeant eorum peccata detegere, propter quod ut plurimi ficte vel male sev nunquam peccata eorum debite confitentur, in animarum periculum parrochianorum huiusmodi et scandalum plurimorum.'

83 GLAUERT, Mario. Michael Junge. In BHRR 1198-1448, S. 688-689; BISKUP, Radosław. Das Domkapitel von Samland (1285-1525). Toruń, 2007, S. 443-445.

84 Codex Epistolaris Saeculi Decimi Quinti. T. II. Coll. Anatolii LEWICKI. Cracoviae, 1891, p. 345-346, No 236: 'plerique ex ipsis parrochianis hoc modo confiteri erubescentes moriuntur non confessi, seu peccatis sordere dinoscuntur in grave periculum animarum'; Codex Diplomaticus Warmiensis..., Bd. IV, S. 598-599, Nr. 580; Bullarium Poloniae. T. V: 1431-1449. Ed. et cur. Irena SUŁKOWSKA-KURAŚ, Stanisław KURAŚ. Romae, Lublin, 1995, p. 267-268, No 1445. 
out, interpreters had to have a high position in the community, which could have discouraged people from confessing their sins in their presence. ${ }^{85}$

Despite the efforts of the Church authorities, the tradition of using interpreters by the clergy seems to have been well established. ${ }^{86}$ This was emphasised by the visitation to the bishopric of Samland in 1569. Although it is a modern source, it reflects the problem very well. It may be a matter for discussion, but I think we can assume that a hundred years earlier local priests had the same problems. Using interpreters was nothing new, but a long-term tradition reaching back to the 13th century. In this visitation tolken were very often listed in local parishes: they are mentioned in the case of almost all of them. ${ }^{87}$ Most accounts say that employing an interpreter was allowed if the parish priest did not know the language (wann der Pfarherr nicht Preussisch khan, muß ein Tolck gehalten werden). Therefore, it is difficult to determine the actual scale of the phenomenon. Nevertheless, the very awareness of such a possibility is symptomatic. Usually, the interpreter was paid from four to six marks. In the case of the tolk of Thierenberg (today Дунаевка), it was underlined that the fact of his also fulfilling other functions in the community made it difficult for him to reconcile them with his work as a regular interpreter. As a result, his salary was raised from two to four marks, limiting his activities to supporting the parish priest in the pastoral care of people who failed to speak German. ${ }^{88}$ In turn, in the parish of Schaaken (today Некрасово), according to Undeutschen's will, an interpreter was employed, being paid only 2.5 marks for many years, and three marks for one or two years. At some point, he complained about his low salary, and from then on was to receive six marks. It was recorded that he had much work, because neither the parson nor the chaplain spoke the language of their parishioners. ${ }^{89}$ At least on the basis of these late records, it can be assumed that in late medieval practice, the lack of knowledge of the parishioners' language was common among the rural clergy, especially in the northeast territories of the Teutonic Order.

85 BRAUER, M. Op. cit., S. 167.

86 See BISKUP, M. Etniczno-demograficzne przemiany..., s. 134, 143; BISKUP, M. Uwagi o problemie osadnictwa..., s. 166. Cf. SZWEDA, A. Mehrsprachigkeit in Preußen... (forthcoming).

87 Wizytacja biskupstwa sambijskiego z 1569 roku. Wyd. Jacek WIJACZKA. Toruń, 2001, s. 38, 59, 75, 90, 109, $131,150,174,199,223,244,316,333,345,352,361,376$.

88 Ibid., s. 75.

89 Ibid. s. 316: 'weyl er gleichwol in der Kirchen zu Tolcken und neben dem Pfarhern und Caplan, wan sie der sprachen unkundig nicht geringe Arbeit tragen mus.' 


\section{Conclusions}

This article was intended to draw attention to the language problems in Prussia strictly in relation to the lower clergy. I have analysed just a few source examples, as a good introduction to further research. It would be worthwhile looking especially for sources that are more practical than normative. Nevertheless, these short remarks allow us to make some initial conclusions. Expectations for a good pastor included the ability to use the language of all parishioners. It seems, however, that this was more a request than a reality. It occurred mainly in cities where there were chaplains for the Polish-speaking population. The situation was certainly different in rural parishes, especially with a large number of believers who spoke only Prussian. This affected the daily functioning of the clergy, both in pastoral and financial terms. For many priests, the permanent employment of a chaplain, or even an interpreter, could be a huge financial burden. In the event of a shortage of bilingual priests, they should theoretically have had great career opportunities. However, the career was mainly determined by ties with prebends' patrons, not language skills. In practice, therefore, the bilingualism of the clergy does not seem to be a factor facilitating a Church career. The lack of knowledge of the language was a problem, but skills in this area did not seem to be a key asset that could determine taking over a parish. A priest in the multilingual Church did not have to be a linguist.

\section{Translated by Agnieszka Chabros}

\section{Acknowledgement}

The article is based on the doctoral thesis entitled 'Clerus et cives. Niższe duchowieństwo w miejskiej przestrzeni społecznej późnośredniowiecznych Prus' (Clerus et cives. The Lower Clergy in the Social Space of Towns in Late Medieval Prussia), written under the supervision of Professor Andrzej Radzimiński. The author obtained funding as part of a doctoral scholarship from the National Science Centre, No 2016/20/T/ $\mathrm{HS} 3 / 00471$. This dissertation is currently being prepared for publication in print. The article was supplemented with the results of research conducted under the project 'Medieval Accounts of Toruń's Churches: Study, Edition, Digitalisation' (NCN OPUS, No 2016/23/B/HS3/00751), carried out under the supervision of Professor Piotr Oliński. The author is one of the participants. 
List of printed sources quoted in the article

Bullarium Poloniae. T. V: 1431-1449. Ed. et cur. Irena SUŁKOWSKA-KURAŚ, Stanisław KURAŚ. Romae, Lublin, 1995.

Codex Diplomaticus Warmiensis. Bd. I: Urkunden der Jahre 1231-1340. Hrsg. von Carl Peter WOELKY, Johann Martin SAAGE. Mainz, 1860.

Codex Diplomaticus Warmiensis. Bd. IV: Urkunden der Jahre 1424-1435 und Nachträge. Hrsg. von Viktor RÖHRICH, Franz LIEDTKE, Hans SCHMAUCH. Braunsberg, 1935.

Codex Epistolaris Saeculi Decimi Quinti. T. II. Coll. Anatolii LEWICKI. Cracoviae, 1891.

Constitutiones synodales Warmienses, Sambienses, Pomesanienses, Culmenses, necnon provinciales Rigenses. Ed. Franz HIPLER. Brunsbergae, 1899.

Formularz z Uppsali. Późnośredniowieczna księga formularzowa biskupstw pruskich (Fontes - Towarzystwo Naukowe w Toruniu, t. 109). Red. Radosław BISKUP. Toruń, 2016.

Księga ławnicza Nowego Miasta Torunia (1387-1450) (Fontes - Towarzystwo Naukowe w Toruniu, t. 63). Wyd. Karola CIESIELSKA. Warszawa, Poznań, 1973.

Księga ławnicza Starego Miasta Torunia (1479-1515). Cz. 2: (1502-1515) (Fontes - Towarzystwo Naukowe w Toruniu, t. 113). Wyd. Krzysztof KOPIŃSKI, Krzysztof MIKULSKI, Janusz TANDECKI. Toruń, 2018.

Lucas David's [...] Preussische Chronik. Bd. II. Hrsg. von Ernst HENNIG. Königsberg, 1812.

Nowa księga rachunkowa Starego Miasta Elblaga (1404-1414). Cz. 2: (1411-1414) (Fontes - Towarzystwo Naukowe w Toruniu, t. 73). Red. Markian PELECH. Warszawa, Poznań, Toruń, 1989.

Ordinancia castri Heylsbergk. In Scriptores Rerum Warmiensium. Bd. I. Hrsg. von Carl Peter WOELKY, Johann Martin SAAGE. Braunsberg, 1866, S. 314-347.

Preussisches Urkundenbuch. Politische Abtheilung. Bd. I, 1. Hälfte. Hrsg. von Rudolf PHILIPPI, Carl Peter WOELKY. Königsberg, 1882.

Repertorium Germanicum. Bd. V: Eugen IV. (1431-1447). Bearb. von Hermann DIENER, Brigide SCHWARZ, Red. Christoph SCHÖNER. Tübingen, 2004.

Statuta Synodalia Dioecesis Wladislaviensis et Pomeraniae. Coll. et ed. Zenon CHODYŃSKI. Varsaviae, 1890.

Urkundenbuch des Bisthums Culm. Bd. I, Th. 2: Das Bisthum Culm unter Polen. 1466-1774. Bearb. von Carl Peter WOELKY. Danzig, 1887.

Eine Verordnung Papst Martin V. über die preußische Sprache in Ermland. Pastoralblatt für die Diöcese Ermland, 1891, 23. Jhg., Nr. 7, S. 90.

Vetera monumenta Poloniae et Lithuaniae gentiumque finitimarum historiam illustrantia: maximam partem nundum edita ex tabulariis Vaticanis. T. II: 1410-1572. Ab Augustin THEINER. Romae, 1861. Wizytacja biskupstwa sambijskiego z 1569 roku. Wyd. Jacek WIJACZKA. Toruń, 2001.

List of previous studies quoted in the article

ADAMSKA, Anna. Czy potrzebna nam jest społeczna historia języka? In Historia społeczna późnego średniowiecza. Nowe badania. Red. Sławomir GAWLAS, Michał T. SZCZEPAŃSKI. Warszawa, 2011, s. $189-202$.

BIAŁUŃSKI, Grzegorz. Bando - pleban pasłęcki. Przyczynek do kariery Prusów w państwie zakonu krzyżackiego. In Ad fontes: Studia ofiarowane Księdzu Profesorowi Alojzemu Szorcowi w siedemdziesięciolecie urodzin. Red. Zoja JAROSZEWICZ-PIERESŁAWCEW, Irena MAKARCZYK. Olsztyn, 2006, s. 52-59.

BISKUP, Marian. Etniczno-demograficzne przemiany Prus Krzyżackich w rozwoju osadnictwa w średniowieczu (o tak zwanym nowym plemieniu Prusaków) [1991]. In BISKUP, Marian. Opera minora: studia z dziejów zakonu krzyżackiego, Prus, Polski i krajów nadbałtyckich. Toruń, 2002, s. 129-150.

BISKUP, Marian. Uwagi o problemie osadnictwa i sieci parafialnej w Prusach Krzyżackich w XIV i XV wieku [1983]. In BISKUP, Marian. Opera minora: studia z dziejów zakonu krzyżackiego, Prus, Polski i krajów nadbałtyckich. Toruń, 2002, s. 151-172. 
BISKUP, Radosław. Das Domkapitel von Samland (1285-1525). Toruń, 2007.

BORAWSKA, Teresa. Buls (Bols, Bulsz, Booltz) Kaspar. In Słownik biograficzny kapituły warmińskiej. Red. Jan GUZOWSKI. Olsztyn, 1996, s. 29.

BORAWSKA, Teresa. Kuhschmalz (de Resel) Franciszek. In Słownik biograficzny kapituły warmińskiej. Red. Jan GUZOWSKI. Olsztyn, 1996, s. 137-138.

BORAWSKA, Teresa. Lumpe (alias Cannengiesser) Andrzej. In Słownik biograficzny kapituły warmińskiej. Red. Jan GUZOWSKI. Olsztyn, 1996, s. 155.

BORAWSKA, Teresa. Sorbom (Sauerbaum) Henryk. In Słownik biograficzny kapituły warmińskiej. Red. Jan GUZOWSKI. Olsztyn, 1996, s. 230-231.

BORAWSKA, Teresa. Stryprock (Streifrock) Jan. In Słownik biograficzny kapituły warmińskiej. Red. Jan GUZOWSKI. Olsztyn, 1996, s. 238-239.

BORAWSKA, Teresa. Wichard (Heilsberg). In Słownik biograficzny kapituły warmińskiej. Red. Jan GUZOWSKI. Olsztyn, 1996, s. 274.

BORAWSKA, Teresa. Życie umysłowe na Warmii w czasach Mikołaja Kopernika. Toruń, 1996.

BORZYSZKOWSKI, Marian. Szkoły diecezji warmińskiej w okresie od XIII do połowy XVI wieku. Studia Warmińskie, 1965, t. II, s. 31-63.

BRAUER, Michael. Die Entdeckung des ,Heidentums' in Preußen. Die Preußen in den Reformdiskursen des Spätmittelalters und der Reformation (Europa in Mittelalter: Abhandlungen und Beiträge zur historischen Komparatistik, Bd. 17). Berlin, 2011.

BÜNZ, Enno. Das Sprachenproblem in der mittelalterlichen Pfarrseelsorge. Beobachtungen in den Lausitzen und anderen Landschaften der Germania Sacra. In Sprachwandel im Deutschen (Lingua Historica Germanica, Bd. 19). Hrsg. von Luise CZAJKOWSKI, Sabrina ULBRICH-BÖSCH, Christina WALDVOGEL. Berlin, Boston, 2018, S. 469-479.

CZAJA, Roman. Dzieje miasta w średniowieczu (XIII wiek- 1466 rok). In Brodnica. Siedem wieków dziejów miasta. Red. Jerzy DYGDAŁA. Brodnica, 1998, s. 81-106.

DOBROSIELSKA, Alicja. Opór, oportunizm, współpraca. Prusowie wobec zakonu krzyżackiego w dobie podboju. Olsztyn, 2017.

GLAUERT, Mario. Michael Junge. In Die Bischöfe des Heiligen Römischen Reiches 1198-1448. Ein biographisches Lexikon. Hrsg. von Erwin GATZ, Clemens BRODKORB. Berlin, 2001, S. 688-689.

GÓRSKI, Karol. Problemy chrystianizacji w Prusach, Inflantach i na Litwie [1982]. Komunikaty Mazursko-Warmińskie, 1997, nr. 3, s. 503-520.

GÓRSKI, Karol. Zanik dawnych Prusów. Zapiski Historyczne, 1982, t. 47, z. 4, s. 81-88.

GÓRSKI, Karol; GOŁEMBIOWSKI, Maciej. Wykaz prebend kościelnych Torunia z 1541 roku. Zapiski Historyczne, 1977, t. 42, z. 4, s. 149-175.

GÜNTHER, Otto. Andreas Slommow und Johannes Zager in den Handschriften der Danziger Marienbibliothek. Zeitschrift des Westpreussischen Geschichtsvereins, 1917, Hf. 57, S. 143-159.

JARZEBOWSKI, Marc. Die Residenzen der Preussischen Bischöfe bis 1525. Toruń, 2007.

JÓZEFCZYK, Mieczysław. Średniowiecze Elblaga. Z problematyki społeczno-religijnej. Elbląg, 1996.

KARP, Hans-Jürgen. Kuhschmalz, Franz. In Die Bischöfe des Heiligen Römischen Reiches 1448-1648. Ein biographisches Lexikon. Hrsg. von Erwin GATZ, Clemens BRODKORB. Berlin, 1996, S. 398.

KOPIEC, Jan; GLAUERT, Mario. Heinrich Sorbom (Sauerbaum). In Die Bischöfe des Heiligen Römischen Reiches 1198-1448. Ein biographisches Lexikon. Hrsg. von Erwin GATZ, Clemens BRODKORB. Berlin, 2001, S. 184-185.

KOPIEC, Jan; GLAUERT, Mario. Johannes Stryprock (Streifrock). In Die Bischöfe des Heiligen Römischen Reiches 1198-1448. Ein biographisches Lexikon. Hrsg. von Erwin GATZ, Clemens BRODKORB. Berlin, 2001, S. 184.

KOSMAN, Marceli. Zanik pogaństwa w Prusach. Komunikaty Mazursko-Warmińskie, 1976, r. 20, nr. 1 (131), s. 3-29.

KRAJNIAK, Radosław. Andreas Lumpe. In Gedanopedia, URL: <https://www.gedanopedia.pl/ gdansk/?title=LUMPE_ANDREAS>, accessed 27 October 2020. 
KRAJNIAK, Radosław. Die Prälaten und Kanoniker des ermländischen Domkapitels bis 1466. Zeitschrift für die Geschichte und Altertumskunde Ermlands, 2020, Bd. 64, S. 100-111.

KROLLMANN, Christian. Eine merkwürdige samländische Urkunde. Altpreußische Forschungen, 1934, 11. Jhg., S. 32-38.

KUBICKI, Rafał. Testamenty elbląskie. Studium z dziejów miasta i jego mieszkańców w późnym średniowieczu. Gdańsk, 2020.

MERKELIN, Jan. Liber de instructione simplicium sacerdotum. Pars 1 (Textus et Studia. Historiam Theologiae in Polonia Excultae Spectantia, vol. 12, fasc. 1). Pub. Marian BORZYSZKOWSKI. Warszawa, 1982.

MIKULSKI, Krzysztof. Struktura etniczna mieszkańców i status społeczny ludności pochodzenia polskiego w Toruniu od końca XIV do połowy XVIII wieku. Roczniki Humanistyczne, 1997, t. 63, s. 111-129.

Multilingualism in the Middle Ages and Early Modern Age. Communication and Miscommunication in the Premodern World (Fundamentals of Medieval and Early Modern Culture, vol. 17). Ed. by Albrecht CLASSEN. Berlin, Boston, 2016.

MOŻDŻEŃ, Julia. Synkretyzm religijny Prusów na podstawie kroniki Szymona Grunaua. Pruthenia. Pismo poświęcone Prusom i ludom battyjskim, 2011, t. VI, s. 221-248.

PÄSLER, Ralf G. Zur Sprachensituation im Deutschordensland Preussen. Ein Problemaufriss. In Ostmitteldeutsche Schreibsprachen im Spätmittelalter (Studia Linguistica Germanica, vol. 89). Hrsg. von Luise CZAJKOWSKI, Corinna HOFFMANN, Hans Ulrich SCHMID. Berlin, New York, 2007, S. 93-107.

RADZIMIŃSKI, Andrzej. Chrystianizacja i ewangelizacja Prusów. Historia i źródła. Toruń, 2011.

RADZIMIŃSKI, Andrzej. Die Kirche im Deutschordensstaat in Preußen (1243-1525). Organisation - Ausstattung - Rechtsprechung - Geistlichkeit - Gläubige (Prussia sacra, 4). Toruń, 2014.

RADZIMIŃSKI, Andrzej. [Review of:] Michael Brauer, Die Entdeckung des „Heidentums" in Preußen... Zapiski Historyczne, 2014, t. 79, z. 3, s. 183-188.

SUMOWSKI, Marcin. Duchowieństwo parafialne Nowego Miasta Torunia i jego społeczne oddziaływanie w średniowieczu. In Nowe Miasto Toruń. 750 lat lokacji. Red. Krzysztof MIKULSKI, Piotr OLIŃSKI, Waldemar ROZYNKOWSKI. Toruń, 2014, s. 85-99.

SUMOWSKI, Marcin. Duchowni diecezjalni w średniowiecznym Toruniu. Studium prozopograficzne. Toruń, 2012.

SUMOWSKI, Marcin. Kler diecezjalny w społeczeństwie średniowiecznego Torunia - przyczynek do badań nad funkcjonowaniem duchowieństwa miejskiego epoki. In Kościół i duchowieństwo w średniowiecznej Polsce i na obszarach sq̨iednich. Red. Radosław BISKUP, Andrzej RADZIMIŃSKI. Toruń, 2013, s. 167-196.

SUMOWSKI, Marcin. Pastor et oves. Parish Priest in Late-Medieval Prussian Town. Quaestiones Medii Aevi Novae, 2018, vol. 23, pp. 345-379.

SUMOWSKI, Marcin. Święcenia duchowieństwa w późnośredniowiecznych Prusach. Roczniki Historyczne, 2019, r. 85, s. 27-68.

SUMOWSKI, Marcin. Wzorzec duchownego w średniowiecznej instrukcji wizytacyjnej Inquisitorium clericorum z diecezji sambijskiej. In Collegarum et Discipulorum Gratitudo. Studia ofiarowane prof. Andrzejowi Radzimińskiemu z okazji 60. urodzin. Red. Radosław BISKUP, Krzysztof KWIATKOWSKI. Toruń, 2018, s. 197-214.

SZWEDA, Adam. Lasset Prewssen Prewssen bleyben. Die Heiden im Ordensland Preußen. Studia historica Brunensia, 2019, vol. 66, no. 2, pp. 159-170. 


\title{
KUNIGAS DAUGIAKALBĖJE BAŽNYČIOJE. KALBA KAIP ŽEMESNIOSIOS DVASININKIJOS FUNKCIONAVIMO ASPEKTAS VĖLYVŲJŲ VIDURAMŽIŲ PRŪSIJOJE
}

\author{
Marcin Sumowski
}

\section{Santrauka}

Analizuodamas daugiausia XV a. ir iš dalies XVI a. pr. Prūsijos (ir Vokiečių ordino valdų Prūsijoje, ir Karališkujų Prūsų, t. y. Lenkijai 1466 m. atitekusios dalies) duomenis, straipsnio autorius siekia atsakyti j klausimą, kiek faktas, kad kunigas mokèjo parapijiečių kalbą, galejo lemti gero parapijos kunigo įvaizdį ir kiek šis vietos kalbos mokejjimas galejjo daryti jtaką tokio kunigo karjerai.

Tyrime atkreiptas dèmesys ị bažnytinių sinodų nuostatus, kurie ipareigojo parapiju kunigus, tinkamai nemokančius parapijiečių kalbos, turèti pagalbininkų kapelionų, mokančių vietos kalbą. Šaltiniai neretai mini lenkų kapelionus Prūsijos miestuose, kurie veikiausiai gelbèdavo klebonams pastoracinejje parapijų veikloje. Atkreiptinas dėmesys, kad dalis lenkų kilmės kapelionų, veikusių miesto aplinkoje, minimi kaip privačių altorių vikarai, taigi lieka klausimas, kiek plačiai jie dalyvavo vietos parapiju pastoracinèje veikloje. Vis dèlto tam tikrais atvejais jie galejo pagelbèti parapiju dvasininkijai, ypač kai ji nemokèjo lenkų kalbos. Prūsų kalbą mokèjusių kapelionų pastebimai trūko, nepaisant to, kad 1449 m. ir 1497 m. Varmijos vyskupijos statutuose irgi buvo pabrèžiama, kad kai parapijoje vartojama vokiečių ir prūsų kalba, klebonas turi užtikrinti prūsų kalbą mokančio kapeliono išlaikymą. Kalbų nemokèjimo problemą Prūsijos dvasininkų terpèje stengtasi spręsti mokant vietos žmones ir juos įšventinant ị kunigus. Tuo tikslu Hailsberge (dab. Lidzbark Warmiński), Varmijos vyskupo pilyje, vietos berniukams buvo įsteigta mokykla.

Viena svarbiausių parapijos kunigų pareigų, kurias numatè bažnytinių sinodų statutai, buvo mokyti žmones tikejjimo tiesų in vulgari, t. y. jiems suprantama kalba. Praktikoje dalies parapijiečių kalbos kunigai nemokèjo, tad šios savo pareigos atlikti negalejjo. Tai ypač akivaizdu mišriose Prūsijos parapijose, kur gyveno tikintieji, kalbejję vokiečių ir prūsų kalbomis. 1426 m. popiežiaus dokumente, kuris pasirode kaip atsakymas i Varmijos vyskupo ir kapitulos užklausą, isakmiai nurodyta, kad j tokias (kalbiškai mišrias) parapijas būtų skiriami tik dvikalbiai kunigai. Tačiau praktikoje buvo įmanoma gauti atleidimą nuo šios prievolès.

Straipsnyje taip pat analizuojamas dvasininkų kilmės Prūsijoje klausimas. Ligšioliniai prozopografiniai tyrimai rodo, kad daugelis dvasininkų buvo kilę iš miestiečių šeimų, o tai lèmè vokiečių kalbos dominavimą dvasininkų terpèje. Pvz., 1480-1481 m. Pomezanijos (Pamedès) vyskupijos dvasininkų sąrašas rodo, kad dvasininkai, kilę iš kaimiškuju vietovių, sudarè mažumą. Prūsų kilmès asmenys taip pat galèjo būti įšventinami ị kunigus (tą numatè Kristburgo sutartis dar 1249 m.), tačiau apie tokius atvejus žinių yra išlikusių labai mažai - istoriografijoje žinoma tik pavienių tokio įšventinimo atvejų. Vokiečiakalbè dvasininkija galèjo neturèti intereso mokytis kitos kalbos, nes tai nebuvo būtina sąlygai jų tolesnei bažnytinei karjerai. Parapijų globėjams, kurie dažniausiai būdavo Vokiečių ordino riteriai, kandidatų i parapijos kunigus ryšiai su vietos valdžia, matyt, buvo svarbesni nei jų kalbiniai igūdžiai. Vyskupų ir kapitulos žemėse buvo įsteigta tik mažesnioji parapijų 
dalis; didesnioji priklausė nuo Vokiečių ordino, tad karjera jose taip pat priklausè nuo nuopelnų Vokiečių ordinui, o ne nuo įgūdžių, būtinų pastoracinei veiklai konkrečioje parapijoje, tinkamumo.

Kai parapiju kunigai prastai mokejjo arba iš viso nemokejjo parapijiečių kalbos, klebonas galèjo samdyti vertèją (tolken). Jau minèti Varmijos vyskupijos 1449 m. ir 1497 m. statutai vertėjams netgi leido užsiimti tam tikra pastoracine veikla, bet tik iki tol, kol parapijos klebonas suras nuolatinį vikarą, mokanti vietos kalbą. Taip pat šaltiniai leidžia kalbèti, jog pamokslai, sakomi vokiečių kalba, iš karto būdavo verčiami ir ì prūsų kalbą, bet dažniausiai buvo taikomas pakaitinio pamokslo modelis: pasakius vokiečių kalba, vèliau jis buvo perpasakojamas vokiečių kalbos nemokantiesiems / nesuprantantiesiems. Tačiau naudojimasis vertejjo paslaugomis buvo problemiškas; tai ypač pasakytina apie išpažinties atlikimą, kai verteju dalyvavimas nesuteikdavo privatumo ir atbaidydavo parapijiečius nuo išpažinties. Tai buvo pažymèta ir Bazelio bažnytinio susirinkimo nuostatuose, apeliuojant i Sembos vyskupo Michaelio Jungès informaciją apie dvasininkus, jo vyskupijos paribiuose ties siena su Žemaitija dar nemokejusius vietos prūsų kalbos. Susirinkimas ipareigojo nesinaudoti vertèjų paslaugomis, skirti tik tokius dvasininkus, kurie mokètų vietos parapijiečių kalbą. Tačiau kai išpažinties metu be vertėjo nebuvo galima apsieiti, jis taip pat būdavo ịpareigojamas saugoti išpažinties paslaptį. Nepaisant bažnytinès vyresnybès pastangu, vertejjų paslaugomis naudotasi dar ir XVI a. antrojoje pusejje. Antai vizituojant Sembos vyskupiją 1569 m., ne kartą minimi vertèjai, su kurių pagalba parapiju dvasininkai bendraudavo su vietos parapijiečiais.

Tyrimas atskleidžia, kad parapijiečių kalbos mokejjimas buvo vienas iš lūkesčių, kurie XVXVI a. Prūsijoje buvo siejami su geru parapijos kunigu. Nepaisant to, igyvendinti ši lūkesti praktikoje buvo gana sudètinga. Vietines kalbas ịvaldęs kunigas veikiau liko siekiamybė nei realybè. 